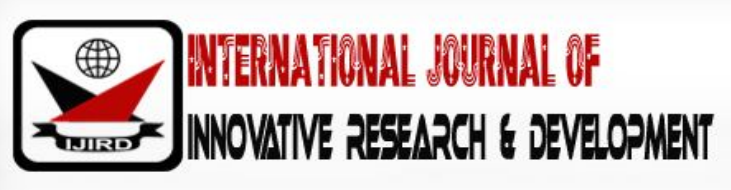

ISSN 2278 - 0211 (Online)

\section{The Role of States and International Institutions in Enhancing Corporate Investment and in Protection of Indigenous People's Right in the Governance of Resources Rich Countries}

\author{
E. E. Alobo \\ Senior Lecturer, University of Calabar, Nigeria \\ K. U. Udungeri \\ Lecturer, University of Calabar, Nigeria
}

\begin{abstract}
:
This article examined the Nigeria oil and gas sector as a case study in discussing the role of the state and international institutions in the area of Foreign Direct Investment (FDI) and regulation of the gas sector in Nigeria. In this connection, the paper studied the effects of FDI on the development of Nigerian oil and gas sector. FDI is presumed to profit an unindustrialized country like Nigeria, not only by improving local investment, but also in terms of employment generation, transfer of technology, increased domestic competition, growth in Gross Domestic Product, Balance of Trade benefit and other affirmative economic indexes. The work scrutinized the investment patterns in the oil and gas natural resources and evaluated the legal framework with regards to FDI and the challenges faced in the regulation of the sector. It further evaluated the regulation of multinational corporations operations by the states and underscored the role of international institutions in the regulation of corporate activities. At the end, the work identified inherent lapses and proffered suggestions as to the way forward.
\end{abstract}

Keywords: Oil and Gas, foreign direct investment, international institutions

\section{Introduction}

Natural resources formed a greater part of literature on development issues around poor countries in recent times, our findings showed this erudition has been so fascinating about the crisis emanating from the presence of these resources, we are obliged to agree that resource rich countries are rather "cursed" especially in the African continent, the text shows that problems are sparked by the pervasiveness in resources management and governance.i.

Poor political leadership, economic mismanagement, and social upheaval are the various concerns which significantly form the basis for recurrent cases of natural resources abuse, no doubt these have negatively crushed economic growth and human development, iii one would expect that a more serious and efficient government should attempt to balance economic improvement and social difficulties of stealing, siphoning and starching abroad of the common wealth of the people who heavily rely on the resources in the country for every measure of growth. But what is common amongst these resources rich nations is that, resource reliance tends to influence governments themselves, making them care and unable to resolve disagreements within their territories and so the nation becomes more prone to aggravated conflicts that could led to full blown wars.

Corporate romance, corruption, state weakness, and lack of accountability, iv have been prevalent among the Nations, it is not unexpected that individuals and groups are more likely to rise up, some in arms and others mere agitations against their government when their economic state is bad and getting sadder. These cases are replete with indigenous people who complain about marginalization and abuse of human rights, for example the people of Ogoni in the oil rich region of Nigeria, once poverty and unemployment are prevalent, the possibility of hostility, kidnapping and plundering appears more attractive by comparison, this pattern is worrisome, but this is the case with countries like Nigeria.

\section{Indigenous People's Rights and Conflict}

Several countries with extractive industry that requires sophisticated technologies and expertise for the resource exploration have had to rely on transnational corporations to supply the know-how. Indigenous groups, comprising of people predominantly around the resource location, suffers the effect of the reckless exploration activities, studies have shown that these people experience abject poverty and diseases, ${ }^{\mathrm{v}}$ the people out of frustration have resorted to targeting the facilities of 
the companies and their expensive infrastructure, such as oil and gas pipeline. This attack are also witnessed in other countries with appreciable natural resources, for instance, groups like Aceh (Indonesia), Biafra, MEND, NDVF (Nigeria). Cabinda (Angola), Katanga (ex-Congo), and West Papua (Indonesia), have had to press for self-determination arising from the right abuse.vi Although it is believed that sometimes the leaders of the indigenous people magnify the extent of right abuse for strategic reasons. Be that as it may?

The devastation of the Ogoni and the people has drawn international concerns. The case of the Ogoni people in the Niger-Delta region is endemic, as noted earlier it is plagued with poverty and under-development, and neglect by the Nigerian Government. Environmental degradation is widespread within the region of Niger Delta. This degradationvii is as a result of the corporate activities of Multi-National Corporations(MNCs) operating in the oil and gas sector within Niger Delta. It has been argued that MNCs, due to market demand for petroleum resources, viii are engaging in abysmal acts leading to release of poisonous substances scattering across the atmosphere, water, and land on a comprehensive scale. For the Niger Delta, human right to environmentix is completely devastated, environmental degradation is the fundamental reason for the persistent tension and conflict in the region, exacerbated by the disillusionment of the indigenous people against the federal government who has remained silent on the issues and MNCsx operating in the region. The manifest abuse of human right is further seen in the negative activities of the oil MNCs in consistent gas flaring and regular oil spillage amongst others. Besides, regulation of corporate activities of the MNCs in the oil and gas sector in Nigeria has been a disaster. This is due to a lot of reasons, for example; corruption, lack of political will of the Federal Government; failure of Agency to implement or enforce laws; and the deliberate acts of MNCs disregarding the existing regulations. ${ }^{\mathrm{xi}}$

How exactly are these rights abused? Let us start this way, Nigeria like many African countries is blessed with natural resources but lacks the competence to explore them, hence they rely on the corporations to exploit. Nigeria is one of the global players in the petroleum market and it is Africa's leading producer of oil and gas.xii Nigeria lacks the requisite indigenous manpower in the sector, exploration of the crude is wholly relied on the multinationals corporations, therefore, the desire to use the Nigerian Oil and Gas sector as a case study to evaluate the regulation of corporate operations in area of economic development and sustainable use of the resources on the one part, and to safeguard the environment cannot be over emphasized.

\section{Role of State in Regulation of Corporate Activities}

There exist a reasonable number of laws regulating corporate activities in area of environmental degradation in Nigeria, with particular reference to the liability of the corporations in the oil and gas sector xiii Some of the key laws are such as the Constitution of the Federal Republic of Nigeria, ${ }^{\text {xiv }}$ the Petroleum Act, ${ }^{\text {xv }}$ Oil Pipeline Act, xvi Oil in Navigable Waters Act, xvii Environmental Impact Assessment Act, xviii Associated Gas Re-Injection Act, xix National Oil Spill, Detection and Response Agency Act, and Other Legislations indirectly dealing with Corporate Environmental Liability in Nigeria. There is also a strong push for self-regulation as a new approach towards corporate operations in the sector.x While this push appears plausible, there are doubts as to the practicality of it. The reasons being that, if the command and control approach has not been effective enough to achieve the desired objectives behind the enactment of these statutes, xxi how then will the approach of self-regulation work in the midst of apparent reluctance on the part of government, traced to corruption and the lack of political will to enforce the laws against corporate operations. xxii

There are in Nigeria several government agencies involved in the regulation, enforcement, supervision and monitoring of the corporate activities in the oil and gas sector. Some of the agencies include NESREA; the Department of Petroleum Resources, Federal Ministry of Environment; NNPC; and NOSDRA etc. However, the scope of this article is not wide enough to cover a comprehensive focus on all the laws and agencies, we cannot pretend to cover all the laws and agencies, but a brief look at one or two of the laws and agencies like NESREA and NOSDRA will suffice. The first government agency, The National Environmental Standards and Regulations Enforcement Agency (Establishment) Actxxiii establishes the NESREA pursuant to S.1(1) of the NESREA Act NESREA is charged under S.2 of the Act, with the duty to protect and develop the Nigerian environment, biodiversity protection and sustainable development of Nigeria's natural resources and environmental technology flowing from coordination with relevant stakeholders within and outside Nigeria on matters of enforcement of environmental standards, regulations, rules, laws, policies and guideline.xxiv NESREA jurisdiction does not extend to the oil and gas sector.xxv We will look briefly at NOSDRA and its regulations in the management of oil spill responses occasioned by oil companies in Nigeria.

For example, such regulations like Oil Spill and Oily Waste Management Regulations (OSOWMR), formulated in 2011. This regulation is incidental to the powers conferred on NOSDRA under S.26 of the NOSDRA. S.4(1), OSOWMR provide for liability of owners or operators of oil facilities who discharges oily wastes into navigable water. Furthermore, S.19 of the OSOWMR provides that any owner or operator of oil exploration and development facilities that fail to comply with the provisions of the regulations shall be liable to pay the penalties as provided under S.6(2) and (3) of the NOSDRA Act. The liability is the clean-up of the facilities, payment for damages to the affected communities and payment of a fine to the government through NOSDRA.

The foregoing notwithstanding, the role of government in the regulation of corporations via the mechanisms discussed above has been a misadventure since the MNCs out of control, and have been in default in many occasions yet no stringent sanction have been visited on them as contemplated by the law for the reasons stated hereunder. The regulation of 
the operational conduct of oil and gas MNCs in Nigeria oil and gas sector is one of "command-control" mechanism.xxvi This measure of regulation in Nigeria has so far not impacted on the MNCs, because the enforcement agencies are characteristically underfunded; poorly equipped for the task and in the most part is manned by corrupt officials lacking in regulatory competence and expertise.xxvii This explains the persistent recklessness of oil and gas MNCs in Nigeria. The fact that the agencies are weak is expected because the regulatory agencies are majorly departments and parastatals of government ministries. It follows therefore, that since there exists a principal - agent relationship between the government and regulatory agencies, the result will be not be more than ineffectiveness.xxviii For instance the Department for Petroleum Resources is one of the key regulators of the sector, but it is legally an arm of the Nigeria National Petroleum Corporation.xxix The agencies are lacking independence and are often susceptible to being intimidated and influenced by government officials and powerful individuals to act within their whims and caprices. ${ }^{\mathrm{xxx}}$

Another reason for the resulting ineffective monitoring is the economic, social and political undercurrents in Nigeria. Recall that we did say Nigeria lacks expertise, competence and cannot independently fund exploration of her oil and gas resources, therefore, government and its business is at the mercy of on the MNCs who exploit the oil and gas resources on its behalf.xxi The significance of this arrangement, especially on the part of government has predisposed the citizens to bear the brunt of ecological damage ensuing from oil production activities.xxxii Successive governments in Nigeria have continuously neglected, denied and failed to grow the political will to enforce extant environmental protection laws against the MNCs, because they dread loosing investors in the oil sector. Public regulation is further inhibited expectedly given the fact that Nigerian government operates a joint-venture partnership or production sharing Agreement with the MNCs; where government often hold over 60 percent of equity through the NNPC.xxxii Due to this arrangement, agencies are less empowered to enforce the laws because to do so will be tantamount to government shooting itself in the foot.

The regulatory agencies' officials been fully aware that they serve at the pleasure of the government, are minded on the kind of strategy to adopt, often time it is very likely they will never enforce the laws against oil MNCs, since they are the major benefactors of state revenues and by extension the government, they fear for reasons that their actions may anger government. It is important to reiterate here that; these regulatory bodies are manned by career civil servants whose tenure is at the pleasure of the government, who may exercise it either way; this is commonplace in Nigeria and may go on for many years to come. As long as government remains in Joint-Venture Agreements with oil and gas MNCs, the enforcement of regulation will remain a mirage hence it is often viewed by the government as disadvantageous to its investment in joint venture projects. Therefore, to create safety net for their jobs, regulatory officers must exercise caution not to disappoint the government by daring to enforce the laws against it. The result of this conundrum is that, there is often regulatory ambivalence in the sector, as regulators now regulate to preserve their jobs, by remaining self-serving and to safeguard public interests by way of implementing the regulatory laws in Nigeria. Such contradictions and compromises have seriously negated government's role as enshrined in the constitution. ${ }^{\mathrm{xxiv}}$

\section{The Role of International Institutions in Promoting Accountability, Responsibility and Liability Regime in the Nigeria Oil and Gas Sector}

There is a general believe among academics that MNCs can be regulated by the host state, home state and or international law. ${ }^{\mathrm{xxv}}$ At present there is no binding legal framework in the form of treaty law, or convention in the enforcement of regulation against MNCs operations at the international law arena, largely because MNCs do not enjoy legal personhood in international law, thus there do not constitute subjects of international law for they to be regulated by international law.xxxvi

Although international law arena is customarily the domain of state actors, it has progressively integrated the intergovernmental bodies or international institutions such as the United Nations (UN), the World Bank, the International Monetary Fund (IMF), the World Trade Organization (WTO) and even regional bodies like the European Union, African Union. These bodies have evolved at least two ways to regulate the MNCs activities. Remarkable among them is adoption of international normative instruments such as the 2011 UN Guiding Principles on Business and Human Rights, popularly known as the "Ruggie Guiding Principles', xxxvii the 2011 OECD Guidelines for Multinational Enterprises (OECD, 2011), and the 2000 Global Compact.xxxviii The adoption of these rules indicates the determination of international institutions such as the UN and OECD to foster the regulation of MNCs bearing in mind that there appear to be super agents lording over their host states. Though there are voluntary normative engagements intended to appeal to the MNCs for best behaviour in their operations with the objective of ensuring compliance among other thing on human rights and environmental standard.xxix We shall now briefly examine key features of these guidelines which have been evolved by the international institutions as it relates to oil and gas sector.

\section{International Labour Organization (ILO)}

The ILO's Tripartite Declaration of the Principles Concerning Multinational and Social Policyxl on operation of MNCs came in response to the public outcry as MNCs activities within the period 1960s and 1970s came under intense security, which resulted in the development of a global mechanisms geared at regulation of MNCs. xli The objective of the Declaration as contain in paragraph 2 is to make MNCs economically and socially responsible to keep at marginal level the disputes and problems that may arise from its operations. It is a voluntary document, again envisioned as a guide for MNCs, governments 
and workers groups' relations. xlii Paragraph 8 urges MNCs to give premium to workers right and not to suppress their complaints. Similarly, paragraph 59 further request the MNCs and national stakeholders to liaise with workers' representatives, as they seek to create voluntary resolution of industrial disputes. The reference of superiority of domestic legal regime to the declaration has weaken the chances of the Declaration.xliii As far as the Declaration is concern it is yet to be seen how it hope to serve its purpose in a state like Nigeria where the dominant legal regime at the national level is unimpressive and cannot be relied on especially given the fact that Nigeria laws are hardly enforced or imposed to guaranteed workplace values or standard practices against the Oil and Gas MNCs, like this Declaration has alluded to.

\section{Organization for Economic Cooperation and Development (OECD)}

The OECD develops models guidelines (recommendations) which are often advisory in nature, as benchmark for MNCs operations. These guidelines first emerged in 1976 and later revised in 2000 and with a new chapter on human right in 2011, xliv the OCED Guidelines on MNCsxlv are voluntary and non-binding recommendations. Paragraph 7 of the General Principles attempts to promote self-regulation among MNCs. The Approaches therein are quite comprehensive and are projected to be given effect within the context of domestic legal regime, once incorporated into national legislations by OCED member states. Part IV of the Guidelines covers "employment and industrial relations" while paragraph 10 of the General Principles creates an extended application of the guidelines to cover businesses other than MNCs and sub-contractors; this is one of the highpoints of the guidelines. Another highpoint is in the enforcement mechanism. We reckon that this would constitute the strength of the guidelines, for instance, the implementation, includes National Contact Points (NCP), to be establish by member states geared at promoting the guidelines, gather data, make inquiries and help in resolving disputes between MNCs and workforce in matters contain in the guidelines.xlvi These guidelines were revised in 2011 about the fifth revision since it was first launched in the 1976. There are plausible improvements in the Fifth Amendment which include commendations to states to inspire and encourage adherence to responsible business standards among their companies. . $^{\mathrm{lv} i \mathrm{i}}$

Environmental liability measures established within the guidelines have started having impact on oil and gas MNCs in the operations, particularly with the rigorous advocacy of civil society groups, utilizing the avenues created in these guidelines xlviii For instance using these avenues Amnesty International and Friends of the Earth in January 2011, relied on the OCED National Contact Points (NCPs) and the OCED Committee on International Investment and Multinational Enterprises (CIME), together with the provision of testimony before a Dutch Parliamentary Committee hearing, to register disappointments of the involvement of the Royal Dutch Shell Oil Company in the degradation of the Niger Delta environment with its reckless operations in the region. .lix

Nonetheless, neither of these international and domestic authority and accountability frameworks can eventually hold the MNCs liable and impose sanctions for any infraction of international human rights and environmental damage guidelines. ${ }^{1}$ Further relying on the OCED recommendations, a Chatham House report on oil theft in Nigeria discovered that "in June 2013, an NCP panel in the Netherlands issued a statement criticizing Shell for publishing data that exaggerated oil theft's role as a cause of oil spills in the Niger Delta" although this statement might be correct as incidences of oil bunkering is becoming a daily activity within the region. While the Chatham House report is seen echoing the voices of the people of the regions, the report was seen as a pyrrhic victory for environmental activists and discerning minds within the region.li It is commendable to note that, all the 34 OCED member states, together with 8 non-OCED stateslii are in full implementation of the guidelines and adhering to the recommendations. Regrettably Nigeria is not a member and unfortunately not one of the non-member states cohering to the guidelines. We are hopeful if Nigeria becomes a member the unscrupulous practices of the MNCs in Nigeria will end.

\section{UN Norms}

The United Nations Norms on the Responsibilities of Transnational Corporations and Other Business Enterprises with Regard to Human Rights for Business simple referred to as the Norms, liiiin this document sets out a range of human rights responsibilities on the MNCs, and set out a proper strategy for monitoring and implementation of the Norms. livThe Norms not surprisingly contain measures for weighting states commitment to meeting up the agreed regulatory criterions. However, the low side of these norms, as is usually the case with this kind of documents, is that they lack binding force, thus the MNCs are yet to commit to their relevance.

\section{Conclusion}

Notwithstanding the gradual integration of international human rights and environmental protection standards in international instruments like the Ruggie Principles, OCED Guidelines and UN Global Compact, there are still gaps in the critical aspect of imputation of direct liability of MNCs. Especially in the most likely event that they fail in their responsibility. This therefore brings to question how they can be brought under international law rules. The difficulties faced by the international institutions to bring to book or to render the MNCs accountable for their refusal to observe human rights and environmental standard abroad highlights the need for re-structuring international legal regime so that the extant laws in the global arena can be directly enforced against the MNCs in foreign jurisdictions since the national legal order is very weak. 


\section{End Note}

i C.U. Manus, "Morality and Politics in Nigeria: The Consequence of the Machiavellian Credo (1960-2007)'. In S. Heuser And H. G. Ulrich (Eds) Political Practices and International Order. Proceedings of the Annual Conference of the Societas Ethica, Oxford (2006), Pp. 156-66, At P. 163.

ii Governance is used here as "the process of decision-making and the process by which decisions are implemented or not implemented. "Taken for granted here is that an analysis of governance must necessarily focus on the "formal and informal actors" institutions and policies involved in decision making and implementing (United Economic and Social Commission for Asia and the Pacific, 2010).

iii S. O. Adelana et al, "Environmental pollution and remediation: challenges and management of oil spillage in Nigerian coastal areas" Am, J. Sci. Ind. Res. 834845 and 836-837, 2(6) 2011 See also Amnesty International Nigeria: Petroleum, Pollution and Poverty in the Niger Delta', p. 14 2009 available http:// www.amnesty.org/ en/ library/ asset/ AFR44/ 017/ 2009/ en/ e2415061-da5c-44f8-a73c-a7a4766ee21d/ afr440172009ppdf [Accessed 28 Dec. 2017.

iv M. Ikhariale, "The Koko Incident, the Environmental and the Law" in F. Shyllon (ed). The Law and Environmental in Nigeria, 1989 pp.73-75 (Ibadan Vintage Publishers, g.S. Ogbodo, "Environmental Protection in Nigeria: Two Decades after the Koko incident" Annual Survey of International and Comparative Law (2009) Vol. 15, p. 1(2), available at http:// digitcommons.law.ggu.edu/ cgi/ viewcontent.cgi?article=1125\&context=annlsurvey\&seiredir=1 \&referer $=$ http\%3A\%2F\%2Fwww.google [Accessed Dec. 28, 2017].

v See note 3 Amnesty International (2009). Nigeria Petroleum Pollution and Poverty in the Niger Delta, p. 15.

vi D. Hallowes, Toxic Futures, South Africa in the Cross of Energy Environment and Capital, (South Africa University of KwaZulu-Natal Press, 2011 ), p. 108.

vii G. U. Ojo, "Community Perception and Oil Companies Corporate Social Responsibility Initiative in the Niger Delta" (2012)3(4) Studies in Sociology of Science 11-21 available at http:/ / www.cscanada.net/index.php/ sss/ article/view/j.sss.1923018420120301.600 [Accessed Dec. 28, 2017].

viii Ibid $\mathrm{n} 6$ at p. 108.

ix See Article 24 of the African Charter on Human and Peoples' Rights Year!?

x Ibid n7 at 38 .

xi E. O. Ekhator, "Improving Access to Environmental Justice under the Africa Charter: The Roles of NGOs in Nigeria" International Conference of the African Charter on Human and Peoples rights, University of South Africa, Pretoria, November 5-7, 2012.

xii Energy Information Administration ("EIA") www.eia.doe.gov. (Accessed 20th Dec. 2017).

xiii L. A. Atsegbua. Oil and Gas Law in Nigeria: Theory and Practice (2nd edn. New Era Publication, Benin City, 2004), p. iii.

xiv Cap N24 1999.

xv Cap P10 LFN 2004.

xvi Cap O7 LFN 2004.

xvii Cap 337 LFN 2004.

xviii Cap E12 LFN 2004.

xix Cap 08 LFN 2004.

xx E. Oshionebo 'Transnational corporations, civil society organizations and accountability in Nigeria's oil and gas industry' 2007 African Journal of International and Comparative Law.

xxi R. Ako. "The Judicial Recognition and Enforcement of the Right to Environment: Differing Perspectives from Nigeria and India" (2010) 3 NUJSL. Rev. 423.

xxii E. Oshionebo, Regulating Transnational corporations in domestic and international regimes. An African Case Study. (Toronto; Buffalo: University of Toronto Press, 2009), p. 56.

xxiii Which was promulgated in 2007.

xxiv See Section 2 of NESREA Act.

xxv See Section 7 of NESREA Act.

xxvi For an overview of the laws on environmental protection in Nigeria, see K. Ebeku, Oil and the Niger Delta People in International Law - Resource Rights, Environmental and Equity Issues (2005) and L. A. Atesgbua et al, Environmental Law in Nigeria: Theory and Practice (Lagos: Ababa Press, 2004).

xxvii L. A. Atsegbua, Oil and Gas Law in Nigeria: Theory and Practice (2nd edn. New Era Publication, Benin City, 2004), p. iii. See also Economic Intelligence Agency Nigeria, Country Analysis Brief, April 2003, www.eia.doe.gov. (accessed 20th Nov. 2017).

xxviii C. E. Emole, "Regulation of Oil and Gas Pollution" (1998) 28 (2) Journal of Environmental Policy and Law 103 at P. 109. See also Y. Omoregbe, "Regulation of Oil Industry Pollution in Nigeria" in New Frontiers in Law (E. Azinge ed. Oliz Benin City, 1993), p. 147.

xxix Ladan, M. T. (2011). "Access to environmental justice in oil pollution and gas flaring cases as human right issue in Nigeria at p. 34". Being a Paper presented at a Training Workshop for Federal Ministry of Justice Lawyers Organized by the Institute for Oil and Gas Law, Abuja *Int. J. L. M. 145 Nigeria. 28-30 November, available at http:/ / papers.ssrn.com/ sol3/ papers.cfm?abstract id=2336093 (Accessed 21 October 2017).

xxx The reason why many laws and even the petroleum Act 1969 consider the most beneficial to Nigerian Economy has not witness any significant amendment and the same goes to all other Acts.

xxxi Evaristus Oshionebo Transnational Corporations, civil society organizations and social accountability in Nigeria's oil and gas industry African Journal of International and Comparative Law 2007 Page 2.

xxxii Ibid n26 p. 2.

xxxii G. U. Nwokeji, The Nigerian National Petroleum Corporation and the Development of the Nigerian Oil and Gas Industry History, Strategies and Current Directions (James A. Baker III Institute for Policy of Rice University, 2007), pp. 15-16.

xxiv There cannot be a more fundamental burden than the environmental objectives contained under S.20 of the Constitution into consideration the important role of petroleum resources to the overall economic well-being of Nigeria and the burden of environmental degradation suffered by the communities that inhabit the oil-producing region. The effective regulation of the environment, especially in the Niger Delta area, is no doubt the sine qua non for industrial harmony in oil and gas production in the region. This is all the more important because the region is home to all of Nigeria's petroleum, hosting all of the country's oil wells. An effective sustainable development will.

xxxv Generally, MNCs' activities are vast in their scope, with the UN Conference on Trade and Development (UNCTAD) suggesting that their activities account for well over 75\% of world trade. See generally UNCTAD "Investment Report 2009", cited in A Jonge "Transnational Corporations and International Law: Bringing TNCs out of the accountability vacuum" (2011) 7/11 Critical Perspectives on International Business 66 at 66 . Also see J. Mikler "Global companies as actors in global policy and governance" in J. Mikler (ed) The Handbook of Global Companies (2013, Wiley-Blackwell Publishing) 1 at 4-5 This part of the article focuses on the regulation of MNCs via international mechanisms.

xxxvi E. Mujih 'Co-deregulation of multinational companies operating in developing countries: Partnering against corporate social responsibility?' 16 African Journal of International \& Comparative Law (2008) 249.

xxxvii The UN Human Rights Council endorsed the "Guiding Principles on Business and Human Rights: Implementing the United Nations "Protect, Respect and Remedy" Framework' on 16 June 2011. These Principles were proposed by the UN Special Representative on Business and Human Rights, John Ruggie. Special Representative of the Secretary-General on the issue of Human Rights and Transnational Corporations and other Business Enterprises as part of his report to the Council; see UN Doc. A/ HRC/ 17/ 31, 21 March 2011.

xxxviii Adopted on 26 July 2000 and subject to further iterations and developments on 6 September 2005 and 19 February 2008, respectively, the UN Global Compact is a strategic policy and networking initiative for businesses that are committed to aligning their operations and strategies with ten universally 
accepted principles in the areas of human rights labour, environment and anti-corruption. Among the ten principles that businesses commit to implementing in their activities. Principle 8 provides that they "undertake initiatives to promote greater environmental responsibility' available at e: http:/ / www.unglobalcompact.org/ (last accessed 23 Dec. 2017).

xxxix Regulating environmental responsibility for the multinational oil industry continuing challenges for international law David M. Ong International Journal of Law in Context 2015.

${ }^{x l}$ Available at:

«http:// www.ilo.org/wcmsp5/ groups/ publc@ed_emp/ @emp_ent/ documents/ publication/ wcms_101234pdf (last accessed 20th November 2017).

xli And define ILO's governing body adopted the Declaration in 1977.

xlii The Declaration, Para. 5.

xliii P. Muchlinski Multinational Enterprises and the Law (1 ${ }^{\text {st }}$ ed. 1999, Blackwell) at 460.

xliv See statement by the conference chair at the ministerial special session on the revision of the OCED Guidelines for Multinational Enterprises (27 June 2000), cited in S. Tully "The 2000 review of the OCED Guidelines for Multinational Enterprises" (2001) 50/ 2 International and Comparative Law Quarterly 394. See generally E. Oshionebo "The OCED Guidelines for Multinational Enterprises as mechanism for sustainable development of natural resources: Real solutions or window dressing?" (2013) 17/ 2 Lewis \& Clark Law Review 545.

xlv Available at: http:// mneguidelines.oced.org/ text/ (last accessed 28 Nov. 2017).

xlvi B. Hepple "Labour regulation in international markets" in S Picciotto and R Manye (eds) Regulating International Business: Beyond Liberalization (1999, Macmillan) 183 at 193.

xlvii Guidelines for multinational enterprises: 2011 edition", available at: http:// www.oced.org/ daf/ inv/ mne/ 48004323.pdf (last accessed 28 November 2017).

xlviii Ibid n37 p. 3.

xlix Amnesty International Report 2011.

1 Ibid n37 p.3.

li Katsouris and Sayne, 2013, p. 63.

lii "Guidelines for multinational enterprises 2011 edition" available at: http:// www.oced.org/ dat/ inv/ mne/ 48004323.pdf (last accessed 28 November 2017). (Argentina, Brazil, Egypt, Latvia, Lithuania, Morocco, Peru and Romania): see also "The OCED Guidelines for Multinational Enterprises Frequently asked question", available at: http:/ / www.oced.org/ corporate/ mne/ theocedguidelinesformultinationalenterprisesfrequentlyaskedquestions.htm > (last accessed 28 November 2017).

liii Available at: http:// www.unchr.ch/ huridocda/ huridoca.ns/ (Symbol)/ E.CN.4.Sub.2.2003.12>Rev.2.En last accessed 28 November 2016).

liv Amnesty International "The UN Human Rights Norms for Business: Towards legal accountability" (2004), available at: http:// www.banktrack.org/ manage/ ems_files/download/ the_un human_rights_norms_for_business_towards_legal_accountability/the_un_human_rights_nor ms_for_business_towards_legal_accountability.pdf (last accesséd 28 November 2017.

\section{References}

i. G. U. Ojo, "Community Perception and Oil Companies Corporate Social Responsibility Initiative in the Niger Delta" (2012)3(4) Studies in Sociology of Science 11-21.

ii. M. Ikhariale, "The Koko Incident, the Environmental and the Law" in F. Shyllon (ed). The Law and Environmental in Nigeria, 1989 pp.73-75 (Ibadan Vintage Publishers.

iii. P. Muchlinski Multinational Enterprises and the Law (1st ed. 1999, Blackwell) at 460.

iv. E. O. Ekhator, "Improving Access to Environmental Justice under the Africa Charter: The Roles of NGOs in Nigeria" International Conference of the African Charter on Human and Peoples rights, University of South Africa, Pretoria, November 5-7, 2012.

v. Energy Information Administration ("EIA") www.eia.doe.gov. (Accessed 20 th Dec. 2016).

vi. L. A. Atsegbua. Oil and Gas Law in Nigeria: Theory and Practice (2nd edn. New Era Publication, Benin City, 2004), p. iii.

vii. C.U. Manus, "Morality and Politics in Nigeria: The Consequence of the Machiavellian Credo (1960-2007)'. In S. Heuser And H. G. Ulrich (Eds) Political Practices and International Order. Proceedings of the Annual Conference of the Societas Ethica, Oxford (2006), Pp. 156-66, At P. 163.

viii. S. O. Adelana et al, "Environmental pollution and remediation: challenges and management of oil spillage in Nigerian coastal areas" Am, J. Sci. Ind. Res. 834-845 and 836-837, 2(6) 2011.

ix. G. S. Ogbodo, "Environmental Protection in Nigeria: Two Decades after the Koko Incident" Annual Survey of International and Comparative Law (2009) Vol. 15.

x. G. U. Nwokeji, The Nigerian National Petroleum Corporation and the Development of the Nigerian Oil and Gas Industry History, Strategies and Current Directions (James A. Baker III Institute for Policy of Rice University, 2007).

xi. R. Ako. "The Judicial Recognition and Enforcement of the Right to Environment: Differing Perspectives from Nigeria and India" (2010) 3 NUJSL. Rev. 423.

xii. E. Oshionebo, Regulating Transnational corporations in domestic and international regimes. An African Case Study. (Toronto; Buffalo: University of Toronto Press, 2009), Amnesty International "The UN Human Rights Norms for Business: Towards legal accountability" (2004), available at: http:/ / www.banktrack.org/ manage/ ems_files/ download/ the_un_human_rights_norms_for_business_towards_legal_account

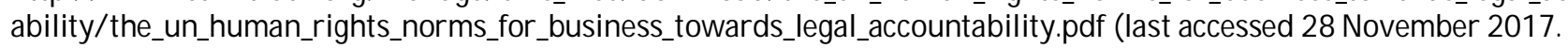

xiii. B. Hepple "Labour regulation in international markets" in S Picciotto and R Manye (eds) Regulating International Business: Beyond Liberalization (1999, Macmillan) 183 at 193.

xiv. D. Hallowes, Toxic Futures, South Africa in the Cross of Energy Environment and Capital, (South Africa University of KwaZulu-Natal Press, 2011), p. 108. 